\title{
Five Stars Teaching Mode of Sports Training Based on APP Microcourse
}

\author{
https://doi.org/10.3991/ijet.v15i06.13617 \\ Yanan $\mathrm{Yu}^{(\bowtie)}$ \\ Shandong Normal University, Jinan, China \\ yynlt@126.com \\ Aili Qi \\ Guizhou University of Engineering Science, Bijie, China
}

\begin{abstract}
With the development of teaching reform, methods and concepts, microcourse teaching has been recognized and developed extensively. However, micro-class pays more attention to the presentation of key contents, and pays less to the teaching design guided by teaching principles, causing the waste of microcourse resources to some extent and affecting the effect of microcourse teaching. Moreover, most of the sports training lectures still follow in the traditional educational pattern of teacher-blackboard-teacher-student, which cannot satisfy students' desire for knowledge and contradict with the demand of social development. Therefore, on the basis of the teaching design of five-star teaching principle, the study focuses on and solves classroom problems, emphasizes the application of knowledge points in different situations, and establishes the relationship between new and old knowledge. Meanwhile, the study combines a new type of Rope Skipping APP microcourse technology, and elaborates the teaching of knowledge rope skipping in the form of microcourse teaching, forming a learning method combined sound and image with pictures. Finally, the study takes learners as the evaluation subject and adopts the analytic hierarchy process to construct five first-level indicators, including value, learning, interaction, technology and art, which makes full use of the expert group's quantitative evaluation on the comparison of the importance of each layer's factors. By constructing the judgment matrix, it calculates the weight value of each index and forms an objective and scientific evaluation index system of microcourse. The results confirm that the teaching mode of the study can be used as the basis for microcourse improvement and auto-recommendation.
\end{abstract}

Keywords-Five stars teaching mode, Rope Skipping APP, Microcourse, Evaluation index

\section{$1 \quad$ Introduction}

As the information technology develops widely and is widely used in classroom teaching, we pay attention to not merely students' acquisition of knowledge, but ways 
of acquisition of knowledge. Among them, microcourse has the advantages of repeated learning, flexible learning time, free from site restrictions, etc. Students with different advantages and characteristics and learning needs can carry out independent learning by integrating fragmented time and knowledge, which is an effective way to strengthen theoretical learning knowledge and a teaching model worthy of reference for the teaching of modern sports training [1]. However, the application of microcourse to sports training teaching is less practical and more controversial. The main controversy is that sports training teaching is mainly based on outdoor teaching and practice and microcourse teaching is more conducive to modern theoretical teaching. Therefore, several important researchers suggest that the application value of microcourse teaching in the education of sports training is insufficient relatively [2].

For students who are receiving systematic education, especially the university education, they still cannot do without the influence and guidance of teachers, and the change of teachers' teaching methods has a great impact on students' learning under such great changes [3].

Firstly, most of the knowledge taught by teachers and the movements demonstrated by them are abstract and difficult for students to understand.

Secondly, in the current microcourse teachings, most of them are video-recording teaching, and knowledge learning emphasizes a transfer teaching without establishing a deep connection between knowledge and practice. The defect is that teaching is not a complete thinking and cognitive process for students to learn knowledge. You don't know to what extent the student's cognitive process is going on and the systematicness and completeness of teaching contents are often neglected in the teaching process [4]. We must prepare a designated time and place for sports, consider the weather restrictions and teachers must be on-site supervision, which will lead to the separation of theory and practice of students, the lower interest in learning, and the loss of new knowledge.

The study takes sports training as the main teaching content of microcourse teaching to evaluate the feasibility of microcourse teaching related to sports. moreover, it combines a five-star teaching theory and builds an objective teaching evaluation index based on it, hoping to improve the teaching efficiency and teaching level of sports training lectures effectively and provide reference for the improvement of related lectures.

\section{State of the Art}

David Penrose, a senior instructional designer at SAN Juan College in New Mexico, USA, pioneered the influential microcourse of one minute micro-video in 2008 [5]. His microcourse was a 60 second course oriented by constructivism, designed for online or mobile learning and recorded by audio or video. His core idea was that teachers were required to link teaching content closely with teaching objectives to produce a more focused learning experience. Then Majid released a video of micro-teaching via the Internet, from which microcourses have been widely 
used [6]. The study project MicroLESSONS, run by the ministry of education, covers a number of curriculum areas, which aims to train teachers to construct microcourse. The lecture usually lasts from 30 minutes to 1 hour, and the teaching objective is simple and concentrated. It pays attention to the creation of learning situations, resources and activities, and provides effective learning supports for students, as well as a series of supports for teachers to help them carry out specific teaching design [7].

In China, the rise of microcourse was discussed by educators in the field of education technology and basic education initially, and then gradually developed into the field of higher education and vocational education, which is still the central point of research in various fields of education. Guan [8] defined microcourse as "microcourse, which was a course designed and developed for knowledge (emphasis, difficulties, doubts, examination, etc.) or teaching links (learning activities, themes, experiments, tasks, etc.) of a certain subject and supported various online video courses. Liang [9] et al. applied microcourse technology in biology course teaching, and they took it as the teaching form and combined with MOOCS, flipped classroom and other new teaching modes to build a series of high-quality microcourses with abundant material resources. Moreover, the emergence of micro lecture has also brought opportunities for the development of sports. Cui [10] applied microcourse to basketball teaching and he built a mobile teaching model of microcourse through the sharing mode design of teacher-led and student-subject, and found that this method was more conducive to giving full play to students' initiative and problem-solving ability.

The training goal of sports training teaching is to promote the formation and improvement of students' sports literacy, promoting the development of sports and cultivate talents with high quality [11]. Sports training teaching is professional, and the content is boring and difficult to grasp. Therefore, the use of information technology teaching and teaching methods is an important condition to improve the effect of learning. microcourse is a new teaching form, there are still some problems in physical education teaching activities, which includes:

- Most teachers can speak fluently and clearly when explaining and demonstrating, while a few teachers do not behave naturally when facing the camera, forgetting words and repeating for many times.

- From the perspective of the application of modern education technology, there are various forms of the present physical education microcourse, but the technical processing including sound quality, video clarity, fluency and post-editing needs to be improved.

- From the perspective of teaching design, it is found that there is a wide range and variety of the existing teaching contents of microcourse of physical education, but there is no relative selection standard for the selection of teaching contents, so that some teaching contents that are not suitable for microcourse are also selected. several teachers ignored the layout of equipment and none of the observed works involved in the design of evaluation of physical education learning results.

Based on the above sufficiency, the paper proposes the microcourse teaching based on the five-star teaching method. The teaching is mainly applied in the course of 
sports training, which is characterized by strong operational and technical requirements for both teachers and students. The innovation of this study lies in: first, it combines the five-star teaching theory to form a network course teaching model with virtual reality function; Secondly, the Loop smart rope skipping platform is adopted as the monitoring platform for students' rope skipping, which can realize the functions of online card punching and data management. Moreover, before the end of the teaching experiment, the evaluation system of five-star teaching method for microcourse was developed with students as the center according to the characteristics of this course.

\section{The Practical Application of Microcourse in Teaching}

\subsection{Integrated five-star teaching method in sports training teaching}

Five star teaching model is a new teaching theory advocated by professor M. David Merrill of Brigham Young university in Hawaii [12], which is used to improve the disadvantages of online teaching, multimedia teaching or E-learning that only emphasize information presentation and ignore the features of effective teaching. The following figure is the construction diagram of the five-star teaching method.

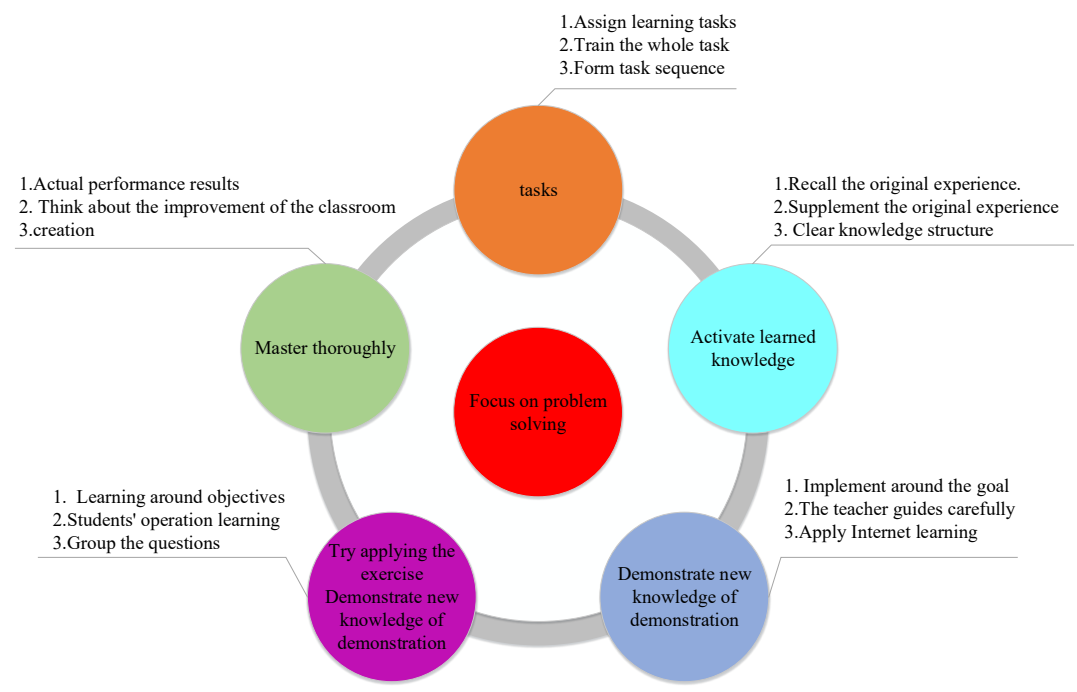

Fig. 1. Construction diagram of the five-star teaching method

Five star teaching mode emphasizes that teaching should follow the cycle of focus on solving problems, and then go through the cycle of activating old knowledge, demonstrating new knowledge, trying to apply and mastering. The outer layer of the figure reflects another cycle composed of structure, guidance, guidance and reflection. Five-star teaching mode focus on teaching emphasis and learners' demand, are widely 
used in different teaching theory, its validity is confirmed in the different understanding of teaching, the five-star teaching concept can guarantee the validity of the products, promote teaching efficiency and learners a highly efficient and reliable to the growth of the teaching mode.

\subsection{Integrated five-star teaching method in sports training teaching}

As can be seen from figure 2, the elements involved in the design process of microcourse mainly include media selection, learner learning, teaching method, teaching activity design, knowledge point design, organizational strategy and scene creation. Through the elements of information dissemination, the above elements are integrated with the evaluation results of sports micro-course. Then it forms four main points of teaching activities, information design, information presentation and learner analysis.

It can be seen from the flow chart of microcourse design that it needs to go through five main processes, including preliminary analysis, scheme design, material preparation, development and production, and test and evaluation. In the process of scheme, teaching content, interface and interaction design need to be carried out to form the script of the overall micro-course. It is necessary to use necessary design tools and software in the process of microcourse design. Mastering the use methods of these software tools becomes a necessary skill for teachers in the process of microcourse design. After the completion of microcourse design is not static, according to the teaching effect and evaluation, reflection and improvement of microcourse is also essential. Fig. 4 and 5 show the practice of microcourse of sports training integrated with the five-star teaching method.

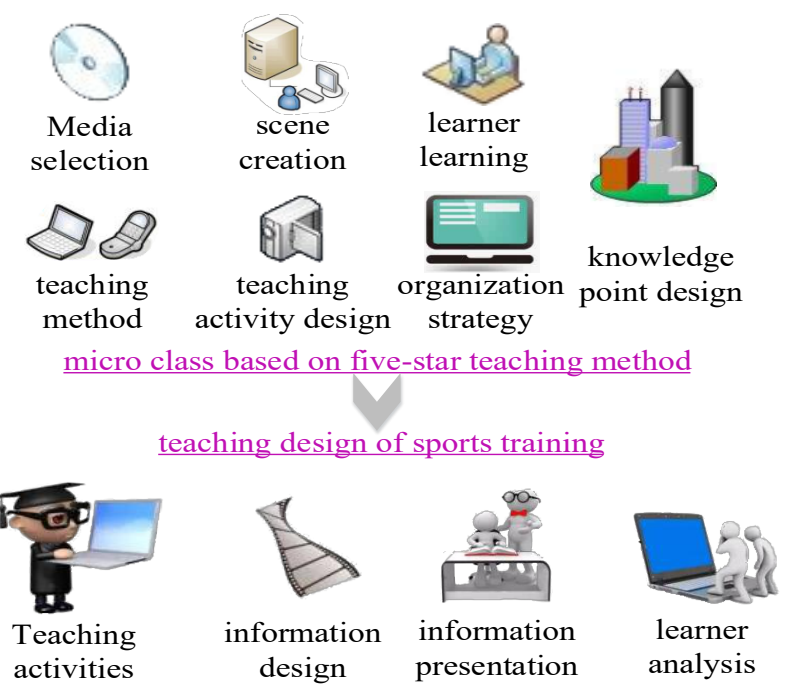

Fig. 2. Selection diagram of microcourse analysis 
Paper-Five Stars Teaching Mode of Sports Training Based on APP Microcourse

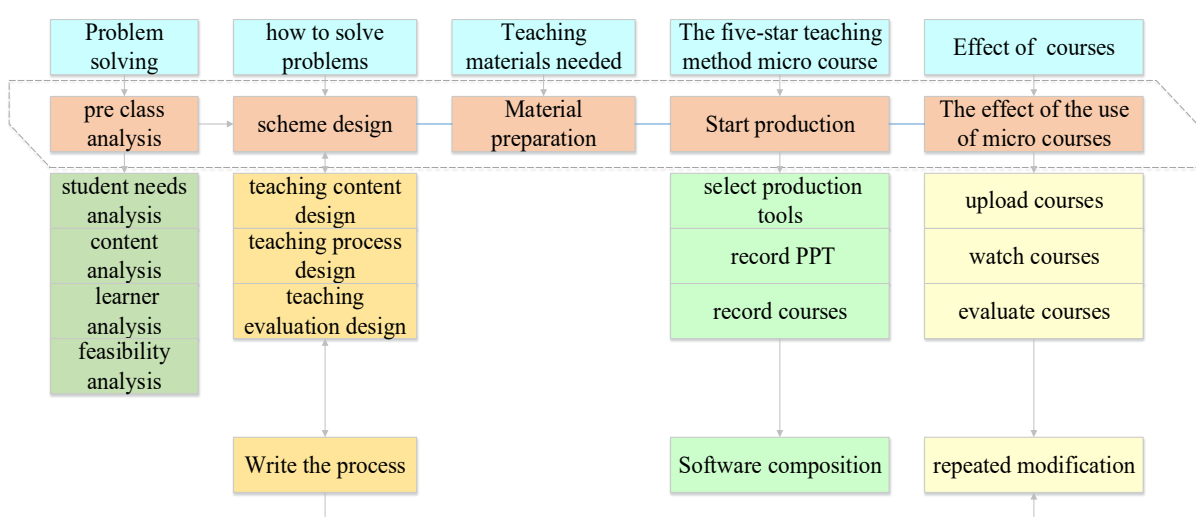

Fig. 3. Flow chart of microcourse design

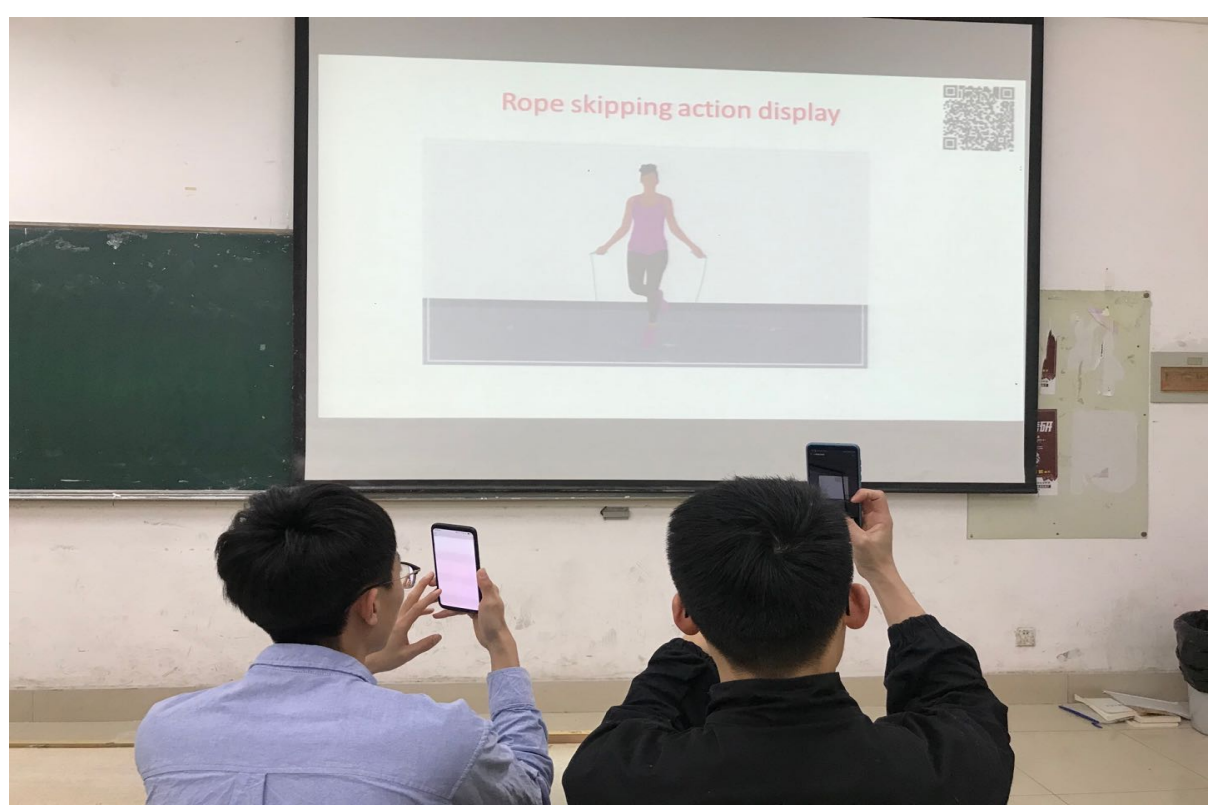

Fig. 4. Practical link 1 of microcourse teaching of sports training integrated with the five-star teaching method 


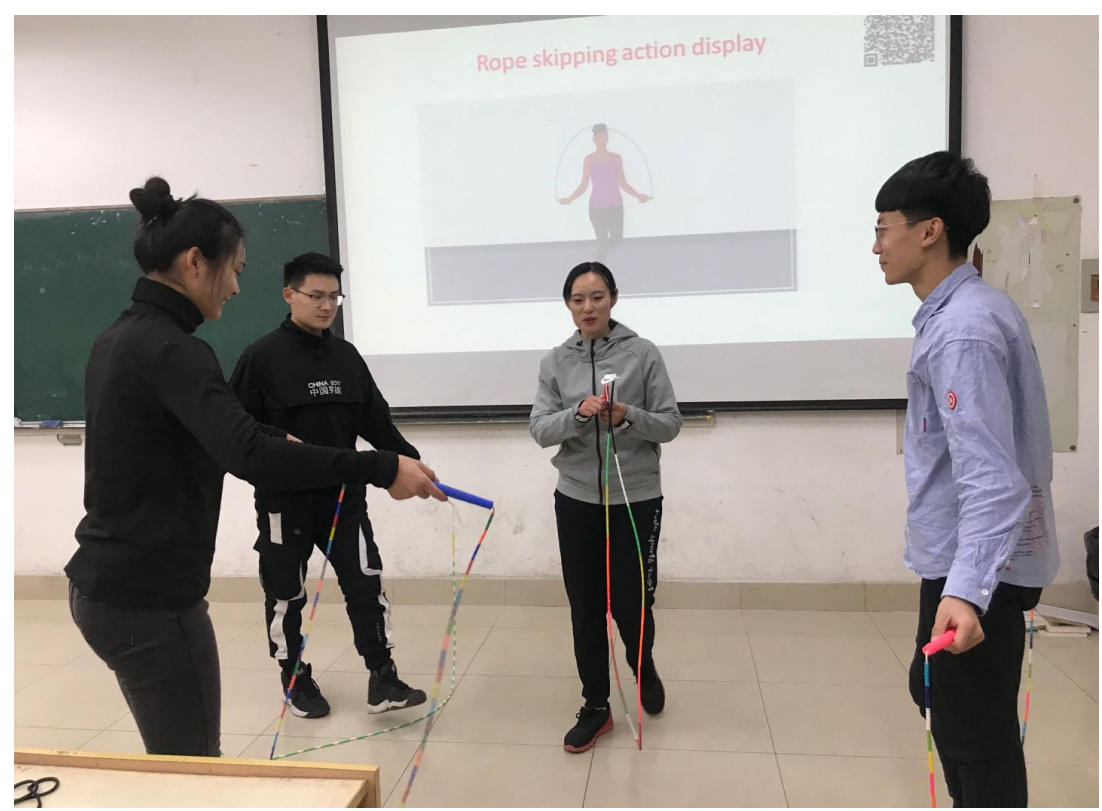

Fig. 5. Practical link 2 of microcourse teaching of sports training integrated with the five-star teaching method

\subsection{Establish the evaluation system of the APP microcourse of sports training based on the five-star teaching model}

Microcourse is a teaching activity with complex structure and many factors involved. In the teaching process, it is necessary to describe the key points, be concise and comprehensive, identify and cover the key contents, but it is not necessary to cover everything[13]. Based on the teaching needs of physical education colleges and universities, the above teaching ladder structure model is designed. In the above model, the goal level is represented by A, the criterion level is represented by $\mathrm{B}$, and the indicator level is represented by C. Among them, level B involves six latitude indexes: value, learning, interaction, technology, art and interest. The C level conducts in-depth decomposition of the above 6 indicators, which is divided into 24 indicators for in-depth analysis. See table 1:

Table 1. Sadie 1-9 scale comparison table

\begin{tabular}{|c|l|c|}
\hline No. & \multicolumn{1}{|c|}{ Definition } & \multicolumn{1}{|c|}{ aij } \\
\hline 1 & The $\mathrm{i}$ factor is as important as the $\mathrm{j}$ factor & 1 \\
\hline 2 & The $\mathrm{i}$ and $\mathrm{j}$ factors are slightly more important & 3 \\
\hline 3 & The $\mathrm{i}$ and $\mathrm{j}$ factor are important obviously & 5 \\
\hline 4 & The $\mathrm{i}$ and the $\mathrm{j}$ factor are more important & 7 \\
\hline 5 & The $\mathrm{i}$ and $\mathrm{j}$ factor are important absolutely & 9 \\
\hline 6 & $2,4,6,8$ lie between $1,3,5,7,9$ & \\
\hline 7 & The judgment value of the $\mathrm{i}$ and $\mathrm{j}$ factor is isaji $=1 /$ aji & \\
\hline
\end{tabular}


Table 1 is the scale comparison table of Sadie $1-9$, and $n^{*} n$ is obtained as the judgment indicator, and the judgment matrix $\mathrm{A}$ is obtained. Taking the first level indicator of the reference level as an example, the judgment opinions of experts are fully combined.

Table 2. First-order index judgment matrix table

\begin{tabular}{|l|c|c|c|c|c|c|}
\hline \multicolumn{1}{|c|}{ A } & $\begin{array}{c}\text { Value } \\
\text { (B1) }\end{array}$ & $\begin{array}{c}\text { Operation } \\
\text { (B2) }\end{array}$ & $\begin{array}{c}\text { Cooperation } \\
\text { (B3) }\end{array}$ & $\begin{array}{c}\text { Technicality } \\
\text { (B4) }\end{array}$ & $\begin{array}{c}\text { Aesthetics } \\
\text { (B5) }\end{array}$ & WI \\
\hline Value (B1) & 1 & 2 & 3 & 3 & 4 & 0.409862 \\
\hline Operation (B2) & $1 / 2$ & 1 & 2 & 2 & 3 & 0.192723 \\
\hline Cooperation (B3) & $1 / 3$ & $1 / 2$ & 1 & 2 & 2 & 0.149145 \\
\hline Technicality (B4) & $1 / 3$ & $1 / 2$ & $1 / 2$ & 1 & 2 & 0.119976 \\
\hline Aesthetics (B5) & $1 / 4$ & $1 / 3$ & $1 / 2$ & 1 & 1 & 0.079221 \\
\hline
\end{tabular}

In table 2, the target layer is set as A and the criterion layer is set as B to establish the judgment matrix (table 2). Yaahp is used to judge the influence weight of the criterion layer on the target layer. In the formula, CI is consistency index and RI is mean random index. The value of RI can be obtained from table 3 . If $\mathrm{CR}<0.10$, it indicates that the judgment matrix satisfies the consistency, that is, the weight coefficient distribution is reasonable; When $\mathrm{CR}>$ is 0.10 , it indicates that the comparison matrix does not meet the consistency, and the element value of the judgment matrix should be adjusted and revised.

Table 3. Index table of average random consistency

\begin{tabular}{|r|c|c|c|c|r|r|r|r|r|r|r|r|r|r|r|}
\hline $\mathbf{n}$ & $\mathbf{1}$ & $\mathbf{2}$ & $\mathbf{3}$ & $\mathbf{4}$ & $\mathbf{5}$ & $\mathbf{6}$ & $\mathbf{7}$ & $\mathbf{8}$ & $\mathbf{9}$ & $\mathbf{1 0}$ & $\mathbf{1 1}$ & $\mathbf{1 2}$ & $\mathbf{1 3}$ & $\mathbf{1 4}$ & $\mathbf{1 5}$ \\
\hline $\mathrm{R} 1$ & 0 & 0 & 0.54 & 0.87 & 1.23 & 1.31 & 1.35 & 1.42 & 1.44 & 1.50 & 1.53 & 1.54 & 1.56 & 1.58 & 1.59 \\
\hline
\end{tabular}

In table 3, Yaahp is used to calculate and judge the maximum characteristic root of the first-order index matrix as lambda Max $=5.091611$, and the consistency

$$
\mathrm{CI}=\frac{\lambda \max -n}{n-1}=\frac{5.091611-5}{5-1}=0.02290275
$$

Mean random consistency index $\mathrm{RI}=1.12$. Therefore, the random consistency ratio $\mathrm{CR}<0.01$.

It can be seen that the results of this hierarchical analysis have A satisfactory consistency, that is, the distribution of weight coefficients is very reasonable. Thus, it can be known that in judgment matrix A, "value B1" the data obtained through formula calculation are shown in table 4. "learning B2" the data obtained through formula calculation are $\lambda \max =4.045820, \mathrm{CI}=0.015273, \mathrm{RI}=0.9, \mathrm{CR}=0.0169<0.10$. "interactivity B3" the data obtained through formula calculation are $\lambda \max =4.081254$, $\mathrm{CI}=0.027084, \mathrm{RI}=0.9, \mathrm{CR}=0.0301<0.10$. "technical $\mathrm{B} 4$ " the data obtained through formula calculation are $\lambda \max =4.081254, \mathrm{CI}=0.027084, \mathrm{RI}=0.9, \mathrm{CR}=0.0301<0.10$. "artistic B5" the data obtained through formula calculation are $\lambda \max =4.140029$, $\mathrm{CI}=0.046676, \mathrm{RI}=0.9, \mathrm{CR}=0.05186<0.10$. 
Table 4. Value (B1) Judgment matrix

\begin{tabular}{|l|c|c|c|c|c|}
\hline \multicolumn{1}{|c|}{ B1 } & $\begin{array}{c}\text { Theme value } \\
\text { (C11) }\end{array}$ & $\begin{array}{c}\text { Target value } \\
\text { (C12) }\end{array}$ & $\begin{array}{c}\text { Feasibility } \\
\text { (C13) }\end{array}$ & $\begin{array}{c}\text { Effectiveness } \\
(\mathbf{C 1 4})\end{array}$ & Weight \\
\hline Theme value (C11) & 1 & 2 & 3 & 3 & 0.453 \\
\hline Target value (C12) & $1 / 2$ & 1 & 2 & 2 & 0.226 \\
\hline Feasibility (C13) & $1 / 3$ & $1 / 2$ & 1 & 1 & 0.141 \\
\hline Effectiveness (C14) & $1 / 3$ & $1 / 2$ & 1 & 1 & 0.141 \\
\hline \multicolumn{2}{|l|}{$\lambda$ max $=4.010336, \mathrm{CI}=0.003445, \mathrm{RI}=0.9, \mathrm{CR}=0.0038<0.10$} \\
\hline
\end{tabular}

\section{$4 \quad$ Teaching Example and Effect}

\subsection{Teaching example}

Microcourse is to integrate fragmented data into efficient teaching courseware and present it to learners, which plays an important role in assisting teaching and improving teaching effect by enriching teaching courseware. Five-star teaching methods can promote the whole teaching knowledge system to form a verified knowledge circle and help learners establish a complete knowledge system. The following Table 5 is the content of the teaching design based on the five-star teaching system.

Table 5. The core of microcourse design for sports training

\begin{tabular}{|c|c|c|}
\hline $\begin{array}{c}\text { Process of } \\
\text { Course Design }\end{array}$ & Target Goal & Measure \\
\hline \multirow{4}{*}{$\begin{array}{l}\text { Focus on } \\
\text { problem solving }\end{array}$} & \multirow{4}{*}{$\begin{array}{l}\text { It focuses on practical problems, clarifies } \\
\text { learning objectives and estimates teaching } \\
\text { effects, and stimulates knowledge } \\
\text { awareness. }\end{array}$} & 1. Clear key points and ask questions \\
\hline & & 2. Sorting out known conditions and resources \\
\hline & & 3. display of expected effect \\
\hline & & Organize teaching activities \\
\hline \multirow{3}{*}{$\begin{array}{l}\text { Activate } \\
\text { original } \\
\text { knowledge }\end{array}$} & \multirow{3}{*}{$\begin{array}{l}\text { Establish the relationship between old and } \\
\text { new knowledge, to realize the purpose of } \\
\text { reviewing the old and learning the new, } \\
\text { and to cultivate students' learning } \\
\text { confidence and interest. }\end{array}$} & Focus on the problem, stimulate thinking \\
\hline & & $\begin{array}{l}\text { Display of videos, pictures and other visual to } \\
\text { promote students to understand quickly }\end{array}$ \\
\hline & & $\begin{array}{l}\text { Establish the practice habit of new and old } \\
\text { knowledge and realize the purpose of } \\
\text { reviewing the old and learning the new }\end{array}$ \\
\hline \multirow{3}{*}{$\begin{array}{l}\text { Demonstrate } \\
\text { new knowledge } \\
\text { of the argument }\end{array}$} & \multirow{3}{*}{$\begin{array}{l}\text { Based on learners' needs and practical } \\
\text { abilities, it carries out the teaching of new } \\
\text { knowledge and the visual display of } \\
\text { teaching knowledge. }\end{array}$} & Display and illustrate actions \\
\hline & & $\begin{array}{l}\text { Introduce specific course, and show visual } \\
\text { teaching resources }\end{array}$ \\
\hline & & Display multi-dimensional key knowledge \\
\hline \multirow{3}{*}{$\begin{array}{l}\text { Try to apply } \\
\text { exercises }\end{array}$} & \multirow{3}{*}{$\begin{array}{l}\text { Combine theory with practice, guide } \\
\text { practice with theory, verify theory with } \\
\text { practice, realize self-test and self- } \\
\text { improvement. }\end{array}$} & $\begin{array}{l}\text { To ensure the new and old knowledge of the } \\
\text { concern }\end{array}$ \\
\hline & & The practice is simple and efficient \\
\hline & & $\begin{array}{l}\text { The difficulty of the exercises needs to match } \\
\text { the learner's ability }\end{array}$ \\
\hline \multirow{3}{*}{$\begin{array}{l}\text { Learn to } \\
\text { integrate }\end{array}$} & \multirow{3}{*}{$\begin{array}{l}\text { Through the process of practice from } \\
\text { simple to difficult, it can stimulate } \\
\text { learners' interest and enthusiasm in } \\
\text { learning, motivate students to continue }\end{array}$} & Summarize the new knowledge \\
\hline & & Multi-scene and multi-level practice \\
\hline & & $\begin{array}{l}\text { Learners ask themselves questions to improve } \\
\text { students' self-learning ability }\end{array}$ \\
\hline
\end{tabular}




\begin{tabular}{|c|c|c|}
\hline & $\begin{array}{l}\text { learning, and cultivate students' ability to } \\
\text { learn from one example and learn from } \\
\text { another. }\end{array}$ & \\
\hline \multirow{2}{*}{$\begin{array}{l}\text { Reflection and } \\
\text { evaluation }\end{array}$} & \multirow{2}{*}{$\begin{array}{l}\text { Summarize new knowledge, refine skills, } \\
\text { check for omissions and make up for } \\
\text { deficiencies, test problem solving ability, } \\
\text { and improve teaching methods of micro- } \\
\text { course. }\end{array}$} & $\begin{array}{l}\text { Teachers and learners evaluate respectively or, } \\
\text { mutually }\end{array}$ \\
\hline & & Do In-class work, and practice next day \\
\hline
\end{tabular}

Table 5 shows that:

- Teaching objectives: It focuses on students' physical health, motor skills, mental health development and social adaptation, as well as social needs, learner ability and needs, with the main purpose of teaching students in accordance with their aptitude, improving the teaching effect and practicality of teaching plans

- The teaching content: Problem orientation, method of rope skipping, expansion content, summary and evaluation. microcourse teaching can guide the interest of students to conclude the case, and the teaching content is from simple to complex. While expanding the teaching content, it can meet the learning needs of learners with different abilities, and finally carry out evaluation and summary, realizing the continuous development of learners and the continuous and perfect development of microcourse teaching

- Teaching process: the process is to activate the old knowledge, demonstrate the new knowledge, try to apply, integrate, evaluate and predict the exercise load, which conforms to the basic process of five-star microcourse teaching, and improves the teaching effect by combining the needs of teaching tasks and taking into account learners' ability and physical and mental health

- Evaluation and summary: The course chooses the training of skipping rope in sports training, which contains basic jumping that requires students to understand the technical characteristics of cars and cooperate with each other. Through microcourse, learners can understand rope skipping in their heart intuitively and clearly, which improves the learning efficiency. Teachers can also observe the learning effect of microcourse from students' actions, and students can also put forward their own doubts and need to improve.

\subsection{Teaching effect}

In order to test the teaching effect of the whole teaching method, the paper selected two classes of Sports Training as the experimental group and the control group, and the students were sophomore students from the same university in China. After the implementation of this teaching method for 15 weeks, two groups of students who used the microcourse of the five-star teaching method and those who did not use this teaching method were evaluated and investigated by questionnaires statistically in the 16th week . According to the results of the survey, students in the experimental group have a better and more comprehensive grasp of sports training techniques, and their satisfaction with the courses is higher than that of the control group significantly. Moreover, through the evaluation analysis of the above five star sports and learner 
intelligence microcourse evaluation index, the weight situation is shown in the table 6 and table 7)

Table 1. Table of synthetic weight of microcourse evaluation index system

\begin{tabular}{|c|c|c|c|c|c|c|}
\hline & \begin{tabular}{|c|} 
Value \\
(B1)
\end{tabular} & $\begin{array}{c}\text { Learning } \\
\text { (B2) }\end{array}$ & $\begin{array}{c}\text { Cooperation } \\
\text { (B3) }\end{array}$ & $\begin{array}{c}\text { Technicality } \\
\text { (B4) }\end{array}$ & $\begin{array}{c}\text { Aesthetics } \\
\text { (B5) }\end{array}$ & weight \\
\hline Level I indicators & 0.410 & 0.193 & 0.149 & 0.120 & 0.079 & \\
\hline Level II indicators & 33.530 & 23.260 & 14.730 & 15.210 & 11.670 & \\
\hline Theme value (C11) & 0.455 & & & & & 18.200 \\
\hline Target value (C12) & 0.262 & & & & & 10.508 \\
\hline Feasibility (C14) & 0.146 & & & & & 5.632 \\
\hline Effectiveness (C15) & 0.161 & & & & & 5.632 \\
\hline Emphasis (C20) & & 0.459 & & & & 11.136 \\
\hline Information Integration (C22) & & 0.226 & & & & 5.486 \\
\hline Practice (C23) & & 0.172 & & & & 4.164 \\
\hline Exercise training (C24) & & 0.144 & & & & 3.906 \\
\hline Smooth use (C30) & & & 0.166 & & & 2.652 \\
\hline $\begin{array}{l}\text { Convenient communication } \\
\text { (C32) }\end{array}$ & & & 0.167 & & & 2.652 \\
\hline Interaction (C35) & & & 0.335 & & & 5.673 \\
\hline Team building (C37) & & & 0.339 & & & 5.390 \\
\hline Arouse interest (C41) & & & & 0.129 & & 1.457 \\
\hline Finish the task (C43) & & & & 0.167 & & 2.010 \\
\hline Ways to learn (C45) & & & & 0.315 & & 3.801 \\
\hline Equipment quality (C47) & & & & 0.380 & & 4.665 \\
\hline Interface design (C51) & & & & & 0.135 & 0.981 \\
\hline Sound effects (C52) & & & & & 0.168 & 1.447 \\
\hline Media selection (C54) & & & & & 0.190 & 0.832 \\
\hline
\end{tabular}

The importance of the secondary index to the overall target is an important basis for evaluating the relative merits of the index layer. The weight of index $\mathrm{C}$ to the $\mathrm{A}$ layer can be obtained by multiplying the total weight of criterion layer B by the weight coefficient of index layer $\mathrm{C}$ in the changing latitude.

Table 2. Evaluation index system of microcourse

\begin{tabular}{|c|c|c|c|}
\hline \multicolumn{2}{|c|}{ Criterion Layer (B) } & Index Layer (C) & Problem of Index Observation \\
\hline \multirow{4}{*}{ Value } & \multirow{2}{*}{$\begin{array}{l}\text { Value of } \\
\text { knowledge }\end{array}$} & Theme value (13) & Whether the subject conforms to the syllabus \\
\hline & & Target value (16) & Whether the goal conforms to the training goal \\
\hline & \multirow{2}{*}{$\begin{array}{l}\text { Value of } \\
\text { ability }\end{array}$} & Feasibility (5) & Whether it is within the student's ability \\
\hline & & Effectiveness (7) & Whether problems can be solved through practice \\
\hline \multirow{4}{*}{ Operation } & \multirow{2}{*}{$\begin{array}{l}\text { Theory of } \\
\text { operation }\end{array}$} & Emphasis (12) & Whether it highlights the point of the lecture \\
\hline & & $\begin{array}{l}\text { Information } \\
\text { integration (15) }\end{array}$ & Whether old and new knowledge is integrated \\
\hline & \multirow{2}{*}{$\begin{array}{l}\text { Practical } \\
\text { operation }\end{array}$} & Practice (5) & $\begin{array}{l}\text { Whether practical activities are designed related to } \\
\text { problems }\end{array}$ \\
\hline & & Exercise training (5) & $\begin{array}{l}\text { Whether training can consolidate and deepen } \\
\text { understanding }\end{array}$ \\
\hline
\end{tabular}


Paper-Five Stars Teaching Mode of Sports Training Based on APP Microcourse

\begin{tabular}{|c|c|c|c|}
\hline \multirow{4}{*}{ Cooperation } & \multirow{2}{*}{$\begin{array}{l}\text { Cooperation } \\
\text { of teachers } \\
\text { and students }\end{array}$} & Smooth use (2) & Whether the equipment operates smoothly \\
\hline & & $\begin{array}{l}\text { Convenient } \\
\text { communication (2) }\end{array}$ & $\begin{array}{l}\text { Whether it is conducive to learning and } \\
\text { communication }\end{array}$ \\
\hline & \multirow{2}{*}{$\begin{array}{l}\text { Cooperation } \\
\text { of students }\end{array}$} & Interaction (6) & Whether the group discussion continues frequently \\
\hline & & Team building (6) & Whether the build team gets the job done \\
\hline \multirow{4}{*}{ Technicality } & \multirow{2}{*}{$\begin{array}{l}\text { Instructional } \\
\text { technology }\end{array}$} & Arouse interest (3) & Whether it can arouse study interest \\
\hline & & Finish the task (4) & Collaborating on multiple learning tasks \\
\hline & \multirow{2}{*}{$\begin{array}{l}\text { Technical } \\
\text { technology }\end{array}$} & Ways to learn (3) & whether the way of learning is convenient \\
\hline & & $\begin{array}{l}\text { Equipment quality } \\
(5)\end{array}$ & Whether PPT and other resources are clear and stable \\
\hline \multirow{4}{*}{ Aesthetics } & \multirow{2}{*}{$\begin{array}{l}\text { Beautiful } \\
\text { scene }\end{array}$} & Interface design (1) & Whether overall layout and hierarchy is reasonable \\
\hline & & Sound effects (1) & $\begin{array}{l}\text { Whether color matching is harmonious and } \\
\text { comfortable }\end{array}$ \\
\hline & \multirow{2}{*}{$\begin{array}{l}\text { Courseware } \\
\text { integration }\end{array}$} & Media selection (5) & Whether the sound, music conforms to the content \\
\hline & & Media art (1) & The training movement can be presented smoothly \\
\hline
\end{tabular}

The above table of microcourse indicator system is based on microcourse learners. Different microcourse textbooks have different effects on different learners, and it is particularly important to teach students according to their aptitude.

\section{Conclusion}

Traditional online and multimedia microcourse teaching may attach importance to information presentation, but as people pay insufficient attention to the teaching process and effect and ignore the teaching process and characteristics of learners, the teaching effect has certain limitations. Based on the research on the teaching application of the microcourse APP of physical training based on the five-star teaching model, the paper draws the following conclusions:

- Microcourse teaching based on five star teaching theory can improve the teaching effect of physical education: The five-star teaching model can relate the new and old knowledge of physical education, realize the purpose of combining the theory and practice of physical education, and realize the efficient physical education by guiding practice with theory.

- The teaching mode can promote learners' physical and mental health: Its core is to focus on the teaching and learning process, which includes students' learning ability and learning needs. The teaching process stimulates students' learning interest with questions, carries out teaching on specific tasks, and shows how the knowledge learned can be applied to the overall task and solve problems. It pays heed to learners' independent learning, which can improve learners' application ability, learning autonomy, enthusiasm and self-confidence. When learners learn knowledge, they can ensure their physical and mental health effectively and not feel frustrated easily.

- Through this experiment, it can be seen that the microcourse model proposed in the paper based on the five-star teaching theory can have application value worthy of 
promotion. Therefore, the teaching mode of sports training can provide a reference for the reform of related teaching and even microcourse teaching.

\section{References}

[1] Chatila, H., Abou Ali, I., Naccache, H., \& Raad, M. Development of an Observation Grid to Evaluate Pre-service Teachers ${ }^{\text {ee }}$ Competences during the Practice Teaching Sessions at the Lebanese University, Faculty of Education. International Journal of Science and Research (IJSR), 2019, vol. 8(8), pp. 1629-1637.

[2] Yang, S.X. Teaching Mode of Dance Appreciation Micro-course Based on Primary Teaching Theory. International Journal of Emerging Technologies in Learning, 2018, vol. 13(8), pp. 133-145. https://doi.org/10.3991/ijet.v13i08.9045

[3] Li, M., \& Ren, Y. A multimedia teaching model for "sports statistics" based on ARCS motivation theory. International Journal of Emerging Technologies in Learning, 2018, vol. 13(9), pp. 15-28. https://doi.org/10.3991/ijet.v13i09.8972

[4] Schoen, R.C., Bray, W., Tazaz, A., Wolfe, C., \& Nielsen, L. Developing an assessment instrument to measure early elementary teachers' mathematical knowledge for teaching. The Elementary School Journal, 2017, vol. 118(1), pp. 55-81. https://doi.org/10.1086/6929 $\underline{12}$

[5] Hou, T., Gou, X., \& Gao, Y. Preliminary application of micro-course in distance education. International Journal of Information and Education Technology, 2016, vol. 6(2), pp. 132-136. https://doi.org/10.7763/IJIET.2016.V6.672

[6] Majid, A., Khan, M. S., \& Ullah, S. Rising prevalence of hepatitis B and C and risk factors at district headquarter teaching hospital Bannu, Khyber Pakhtunkhwa. J Coll Physicians Surg Pak, 2010, vol. 20(7), pp. 492-493.

[7] Shah, N., Hossain, N., Noonari, M., \& Khan, N.H. Maternal mortality and morbidity of unsafe abortion in a university teaching hospital of Karachi, Pakistan. JPMA-Journal of the Pakistan Medical Association, 2011, vol. 61(6), pp. 582-586.

[8] Guan, G.J. classroom teaching reform under the environment of information technology -Analysis of two stages three links classroom teaching mode of "learning case guidance, micro class assistance and cooperative learning". Shanxidianjiao, 2018, vol. 26(3), pp. 4345.

[9] Lian, Y.F., Wei, J.B., Chen, H.Y., et al. Preliminary study of using microlectures to teach Parasitology. Journal of Parasitic Biology, 2014, vol. 9(9), pp. 862-863.

[10] Cui, H.T. The application of basketball flipped classroom teaching based on mobile micro class. Course Education Research, 2017, vol. 5(40), pp. 217-220.

[11] Poussel, M., Laure, P., Latarche, C., et al. Specific teaching about doping in sport helps medical students to meet prevention needs. Science \& Sports, 2013, vol. 28(5), pp. 274280. https://doi.org/10.1016/j.scispo.2013.01.009

[12] Merrill, M.D. A pebble-in-the-pond model for instructional design. Performance Improvement, 2002, vol. 41(7), pp. 41-46. https://doi.org/10.1002/pfi.4140410709

\section{$7 \quad$ Authors}

Yanan Yu is a lecturer in Shandong Normal University, Jinan 250014, China (yynlt@126.com). 
Aili Qi (Correspondence Author) is an associate professor in Guizhou University of Engineering Science, Bijie 551700, China. (qiailili@yeah.net).

Article submitted 2020-01-06. Resubmitted 2020-02-05. Final acceptance 2020-02-06. Final version published as submitted by the authors. 